\title{
THE CONCEPT OF INTELLECTUAL CAPITAL IN LEGISLATION: THE CASE OF LATVIA
}

\author{
Oksana Lentjušenkova ${ }^{1}$, Inese Stankeviča ${ }^{2}$, Inga Lapinana ${ }^{3}$ \\ 1, 2 University of Economics and Culture, Lomonosova iela 1/5, Riga, Latvia \\ ${ }^{3}$ Faculty of Engineering Economics and Management, Riga Technical University, \\ Kalnciema iela 6, Riga, Latvia \\ E-mails: ${ }^{1}$ oksana@augstskola.lv (corresponding author); ${ }^{2 i n e s e @ i n e s e s t a n k e v i c a . l v ; ~}$ \\ Inga.Lapna@rtu.lv
}

\begin{abstract}
Nowdays intellectual capital has become one of most important resources which provide sustainable competitive advantage for a company. Despite it, intellectual capital in companies in Latvia is limited. Previous studies, conducted by the authors, showed that one of the factors that influence intellectual capital in companies is legal protection of intellectual capital. The purpose of the study is to analyse the concept of intellectual capital in legislation in order to clarify the understanding of the concept of intellectual capital. The following qualitative and quantitative research methods have been used: logical and comparative analysis, the deductive method, the statistical method, the empirical method and the induction method. The current study results show that an additional factor, which influences the intellectual capital development in companies in Latvia, is lack of uniform approach to the concept of intellectual capital in legislation.
\end{abstract}

JEL Classification: K11, K29, D23.

\section{Introduction}

In the era of rapid changes in the economic systems and development of management models, the role of new sources of competitive advantage is growing rapidly. Since the 1980 s, scientists have highlighted the importance of intangible assets (Itami \& Roehl, 1987; Reinhardt, Bornemann, Pawlowsky, \& Schneider, 2003; Petrick, Scherer, Brodzinski, Quinn, \& Ainina, 1999; Zack, 2003) and knowledge (Cohen \& Levinthal, 1990; Grant, 1996) as well as intellectual capital (Bontis, Chua, \& Keow, 2000; Edvinsson \& Malone, 1997; G. Roos \& J. Roos, 1997; Stewart, 1991, 1997) for the competitiveness of organizations.

The role of a company's intellectual capital has been recognized at the European Union level (the European Commission has funded a number of research projects on the issues of intellectual capital) as well as at the level of various international organizations (for example, the Organization for Economic Cooperation and Development - OECD) that calls for more attention to efficient use of intellectual capital in business activities. However, in the business environment, the use of intellectual capital is associated with difficulties that reduce its potential for use, such as a common understanding of the concept of intellectual capital, copyright protection mechanisms, lack of financial resources for the acquisition of the necessary amount of intellectual capital, problems of recording these resources in accounting, etc.

Over the last thirty years, there has been a change in the research of intellectual capital: a shift from studies of the impact of intellectual capital on the organization's performance to studies of intellectual capital management has taken place. In the studies about the impact of intellectual capital on financial performance and value creation using a variety of methods, many researchers demonstrate both a positive impact of intellectual capital on the organization's financial performance (Bontis et al., 2000, Pulic, 2000; Subramaniam, 2005; Tseng \& Goo, 2005; Zéghal \& Maaloul, 2010; Wang \& Chang, 2005) and a neutral impact (Puntillo, 2009). Some studies show that physical capital plays a decisive role in ensuring the organization's performance (Chan, 2009a, 2009b; Garanina, 2008). To this group also belongs the dynamic view on intellectual capital, including determining its place in the value creation chain. Over the last ten years researchers have paid special attention to the use of intellec- 
tual capital and its components in the organizational management and value creation, emphasizing that value is not just monetary, but incorporates worth and importance of the products and services to customers and other stakeholders (Dumay, 2009). Edvinsson (2013), who has analysed more than twenty years of intellectual capital research experience, concludes that "too much focus on metrics and measurements means that there is not enough focus on the real strategy process".

One of the burdensome factors of intellectual capital management may be lack of a common understanding and use of different concepts. Despite the fact that several authors have researched the nature of intellectual capital and proposed their definitions of the concept of intellectual capital, there is no unified approach to the understanding of intellectual capital in the scientific literature. Several authors are continuing research into the nature and structure of intellectual capital, proposing new definitions and structures resulting from economic changes. Scientists include not only elements that intellectual capital consists of, but also aspects of value creation and intellectual capital management into the nature of intellectual capital. Kianto, Andreeva, and Pavlov (2013) believes that intellectual capital comprises the valuable knowledge-based resources and the management activities related to them. Today, an important aspect of research is transnational differences in the structure of intellectual capital and the use of management models. Inkinen, Kianto, Vahala, and Ritala (2017), when studying transnational differences in the structure of intellectual capital, discovered that these differences are minimal, despite intercultural diversities. Consequently, each country can use different management models, the effectiveness of which will be more dependent on institutional factors, such as company structure, organizational culture, etc.

One of the factors that influence the development of intellectual capital is copyright protection (Lev, 2000; OECD, 2013). This factor significantly affects the entrepreneurs' decisions on investments in intellectual capital. According to the authors' previous study, copyright protection is one of the worst risks to the company's investments in intellectual capital (Lentjušenkova \& Lapina, 2015).

The existing legal framework in the sphere of copyrights is based on international norms, but it is not always able to provide the necessary protection of intellectual capital of an organization. One of the reasons is use of fragmented terminology, which is significantly different from the terminology used by scientists in researching the nature and structure of intellectual capital. Normative acts, including international ones, do not mention the concept of intellectual capital, but use the concept of intellectual property.

The purpose of the study is to analyse concept of intellectual capital in legislation in order to clarify the understanding of the concept of intellectual capital.

To understand the concept of intellectual capital, the interpretation of this concept in the scientific literature and normative acts has been analysed, and also a study on how Latvian entrepreneurs perceive intellectual capital of has been carried out.

\section{The concept and structure of the company's intellectual capital in the scientific literature}

There are several definitions of intellectual capital in the scientific literature. The nature of intellectual capital has changed due to economic changes and change in the approach to company management. In the 1990s, scientists defined intellectual capital by including some elements of intellectual capital or expanding the concept of knowledge. Later, the nature of intellectual capital was related to the creation of value, including the creation of intangible assets (see Table 1).

To understand the essence of intellectual capital, it is important to analyse the structure of intellectual capital. Today, scientists offer a variety of structures of intellectual capital. The existing structures are mostly different in terms of the degree of detail of components and elements included (scientists divide intellectual capital into a smaller or larger number of components) and the names of the components, while the nature of components is not changed (see Table 2).

When studying the structure of intellectual capital, it can be concluded that intellectual capital at organisational level is traditionally divided into three groups/components: human capital, organizational capital and relational capital. Sveiby (2001) offered another three-component structure: external structure, internal structure and individual competence. The external structure can be seen as a family of intangible relationships with customers and suppliers, which form the basis for the reputation (image) of the firm. The family of Internal Structure can be 
seen to hold patents, concepts, models, templates, computer systems and other administrative more or less explicit processes. These are created by the employees and are generally "owned" by the organisation. The Individual
Competence family consists of the competence of the professional/technical staff, the experts, the R\&D people, the factory workers, sales and marketing.

Table 1. The concept of intellectual capital in scientific literature (some examples) (source: created by authors)

\begin{tabular}{|l|l|}
\hline \multicolumn{1}{|c|}{ Author/Authors } & \multicolumn{1}{c|}{ Definition } \\
\hline Stewart (1991) & $\begin{array}{l}\text { Intellectual capital is the total stocks of the collective knowledge, information, techno- } \\
\text { gies, intellectual property rights, experience, learning and competence, team commu- } \\
\text { nication systems, customer relations, and brands that are able to create values for a } \\
\text { firm. }\end{array}$ \\
\hline $\begin{array}{l}\text { Edvinsson and } \\
\text { Malone (1997) }\end{array}$ & Intellectual capital as knowledge that can be converted into value \\
\hline $\begin{array}{l}\text { Petty and Guthrie } \\
\text { (2000) }\end{array}$ & $\begin{array}{l}\text { Intellectual capital is an indicator that has the ability to generate future earnings or fi- } \\
\text { nancial capital together with an organization }\end{array}$ \\
\hline Jurczak, 2008 & $\begin{array}{l}\text { Intellectual capital is all connected with each other: knowledge resources that the or- } \\
\text { ganization disposes in creating value needed to gaining competitive advantage in long } \\
\text { term. }\end{array}$ \\
\hline $\begin{array}{l}\text { Gogan, Rennung, } \\
\text { Istis, and Drahici } \\
\text { (2014) }\end{array}$ & $\begin{array}{l}\text { Intellectual capital is the way of organizations value creation through its monetary, } \\
\text { nonmonetary, physical and nonphysical resources that have to be identified (know), } \\
\text { use (exploit), measure (evaluate, control) and manage properly. }\end{array}$ \\
\hline $\begin{array}{l}\text { Lentjušenkova and } \\
\text { Lapinga (2016) }\end{array}$ & $\begin{array}{l}\text { Intellectual capital is the organization's asset that includes the organization's human } \\
\text { capital, business processes (procedures and their descriptions), technologies, and in- } \\
\text { tangible assets that can be transformed into tangible and intangible value. }\end{array}$ \\
\hline
\end{tabular}

Table 2. The components of intellectual capital in scientific literature (some examples) (source: created by authors)

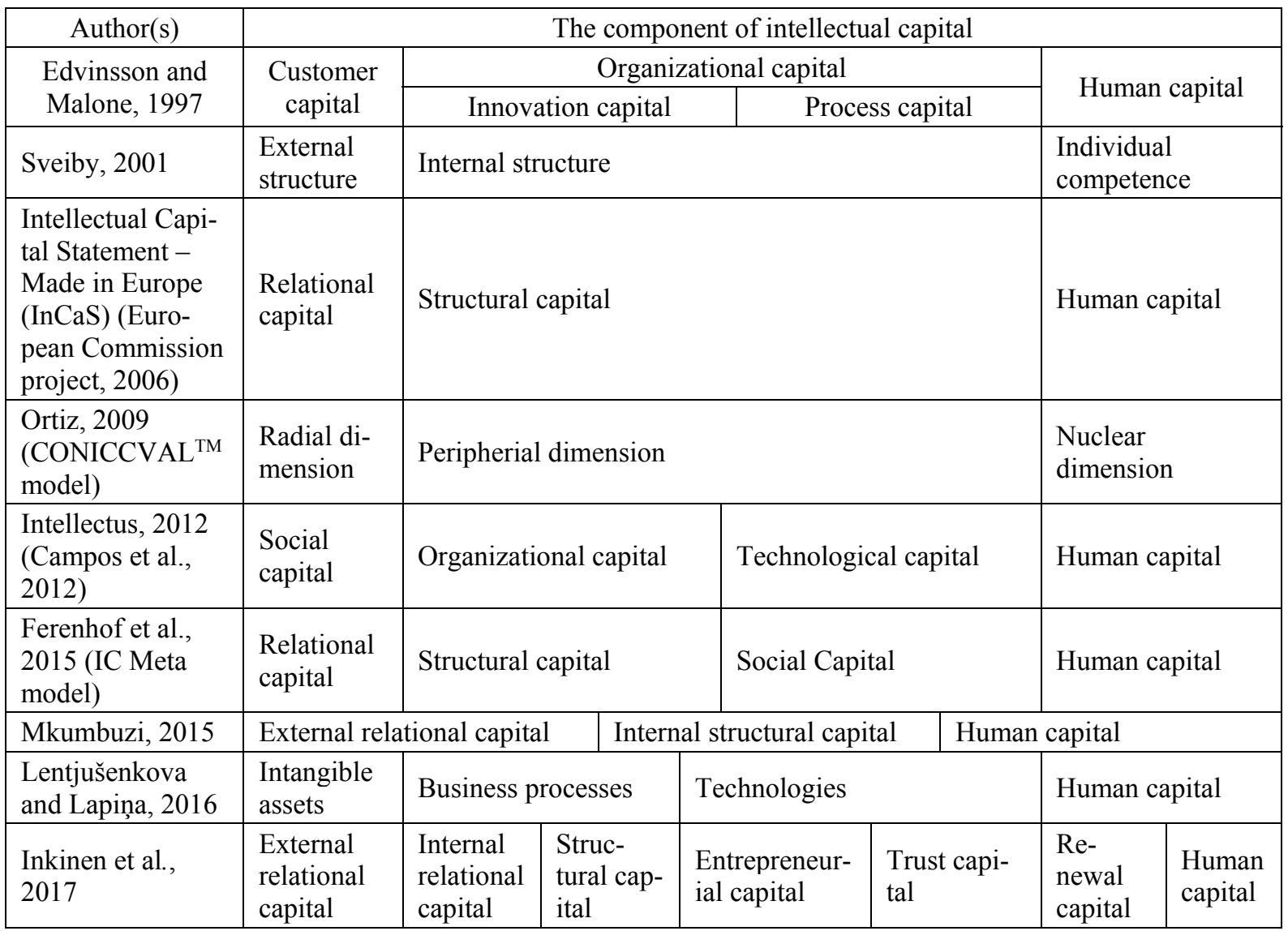


A different approach to the structure of intellectual capital is offered by Ortiz (2009) by creating the CONICCVAL ${ }^{\mathrm{TM}}$ model (contextual intellectual capital components valuation). The components are clustered in three dimensions: nuclear (the components "are intrinsic to the human being and they can only be developed by humans"), radial (the components "are generated by the human capacities") and peripheral (the components "arise as part of the organization's processes, they can be transferred and commercialized"). The form of the model is shaped as a cone where the tip represents the nuclear dimensions.

A seven-component structure of intellectual capital is offered by Inkinen et al. (2017). Researchers identified additional components of intellectual capital: renewal capital, entrepreneurial capital and trust capital. Renewal capital describes the organization's capacity to renew through knowledge-related activities, such as learning and creativity. Entrepreneurial capital consists of the competence and commitment related to entrepreneurial activities within the organisation. Trust capital is an integral part of the organizational climate and culture.

Table 3. The elements of the intellectual capital components (source: Lentjušenkova \& Lapiṇa, 2016)

\begin{tabular}{|c|c|c|}
\hline Human capital & $\begin{array}{c}\text { Organizational } \\
\text { capital }\end{array}$ & $\begin{array}{c}\text { Relational } \\
\text { capital }\end{array}$ \\
\hline $\begin{array}{l}\text { Education } \\
\text { "Know-how" } \\
\text { Professional } \\
\text { qualifications } \\
\text { Professional } \\
\text { knowledge } \\
\text { Competency } \\
\text { Entrepreneurial } \\
\text { ability } \\
\text { Creativity } \\
\text { Ability to } \\
\text { change } \\
\text { Ability to act }\end{array}$ & $\begin{array}{l}\text { Patents } \\
\text { Trademarks } \\
\text { Licenses } \\
\text { Management } \\
\text { model } \\
\text { Organizational } \\
\text { culture } \\
\text { Management } \\
\text { processes } \\
\text { Information } \\
\text { and communi- } \\
\text { cation systems } \\
\text { Computer net- } \\
\text { work systems } \\
\text { Technologies } \\
\text { Computer soft- } \\
\text { ware }\end{array}$ & $\begin{array}{l}\text { Consumer } \\
\text { loyalty } \\
\text { Cooperation } \\
\text { Consumer } \\
\text { database } \\
\text { Supplier da- } \\
\text { tabase } \\
\text { Partnership } \\
\text { Reputation }\end{array}$ \\
\hline
\end{tabular}

In previous studies conducted by the authors a four-component structure of intellectual capital was offered. At organizational level, the authors offered to structure intellectual capital into four components, which would allow the organization to easily enter them in the accounts, use them and analyse their changes: human capital, business processes, technologies and intangible assets (Lentjušenkova \& Lapiņa, 2016).

Each of these components is formed from a variety of elements: knowledge, intellectual property, computer networks, brand, qualification etc. (see Table 3).

Human capital includes elements that are mostly knowledge and knowledge-based. The organizational capital includes those elements that are created using the company's human capital, as well as those elements that may be created outside the company. Relational capital consists of elements that ensure successful sales of the company's products in the market, incl. in the long term.

\section{Understanding of intellectual capital in legislation}

When analysing legislation documents (domestic and international laws and regulations, international conventions) it can be concluded that they do not mention intellectual capital, but use the term "intellectual property".

Rozenfelds (2004) has defined intellectual property as a form of property rights that regulates the rights to non-material things - the products of mental activity, giving the owner monopoly rights to these products of mental activity, and also defining the limits of this monopoly.

According to the World Intellectual Property Organization (WIPO) intellectual property refers to creations of the mind, such as inventions; literary and artistic works; designs; and symbols, names and images used in commerce. The Convention Establishing the World Intellectual Property Organization (WIPO), concluded in Stockholm on July 14, 1967 (Article 2(viii)) provides that "intellectual property shall include rights relating to: literary, artistic and scientific works, performances of performing artists, phonograms and broadcasts, inventions in all fields of human endeavor, scientific discoveries, industrial designs, trademarks, service marks and commercial names and designations, protection against unfair competition, and all other rights resulting from intellectual activity in the industrial, scientific, literary or artistic fields." (WIPO, 2004). The structure of intellectual property significantly differs from the structure of intellectual capital which exists in the scientific literature. The intellectual property includes copyright, patents, trademarks, industrial designs, geographical indications. 
In Latvia, there are seven laws and more than fifteen regulations which regulate intellectual property rights. These laws and regulations are developed in accordance with international regulations and conventions; that is why the main components of intellectual property are similar. Each component of intellectual property and its protection is regulated by separate laws, for example, Copyright Law, Industrial Design Law etc.

However, the law related to intellectual property defines some types of intellectual property which are not mentioned in WIPO. For example, the Commercial Law (Article 19) defines a commercial secret. The status of a commercial secret may be assigned by a merchant for such matters of economic, technical or scientific nature and information, which is entered in writing or by other means or is not entered and complies with the following features: 1) it is contained in the undertaking of the merchant or is directly related thereto; 2 ) it is not generally accessible to third parties; 3 ) it is of an actual or potential financial or non-financial value; 4) its coming at the disposal of another person may cause losses to the merchant; 5) in relation to which the merchant has taken reasonable measures corresponding to a specific situation to preserve secrecy.

In the theory of accounting, the concept "intellectual capital" is hardly ever used. Instead, there are the concepts of "intangible assets" and "intangible investments". In the Latvian law which regulates accountancy intangible investments are included in the annual financial statement as part of long-term investments (Law On the Annual Financial Statements and Consolidated Financial Statements, 2015). Intangible investments are intangible properties other than financial assets and complying with both the following classification criteria: 1) they can be separated or divided from an undertaking and sold, transferred, licenced, rented out or exchanged (individually or together with another liability or asset) or they have arisen from an agreement or other rights regardless of whether such rights are transferrable or separable from the undertaking or from other rights and obligations, 2) an undertaking intends to use them for more than one year and expects that economic benefits will be received from holding of such properties.

The main parts of intangible investments as part of long-term investments of the organization are: 1) development costs, 2) concessions, patents, licences, trademarks and similar rights, 3) intangible value, 4) other intangible investments, 5) advance payments for intangible investments.
International Accounting Standard 38.SGS (IFRS, 2002) defines an intangible assets, as an identifiable non-monetary asset without physical substance.

The structure used in 38.SGS and the Latvian Law On the Annual Financial Statements and Consolidated Financial Statements is based on the investment object, i.e. how or where the organization's financial resources are spent.

When comparing the use of concepts in normative documents, it can be concluded that it is significantly different from the use of concepts in the management literature and economic literature. It should be noted that there are differences in the application of the concepts in the normative acts protecting intellectual property and in the normative acts that regulate accounting in the organization. In addition, different terms are used such as "intangible investments" in Latvian legislation and "intangible assets" in international standards.

\section{Empirical research about the concept of intellectual capital: the view of Latvian entrepreneurs}

Within this study the authors conducted a survey with the purpose to determine the opinion of respondents about the nature of intellectual capital and the importance of intellectual capital elements in the perception of respondents.

The respondents' database was built on the basis of information provid ed by the Latvian Association of Personnel Management, Latvian Business Efficiency Association, Latvian Employers' Confederation Vidzeme Division and Latvian Quality Association. The total number of respondents is 203 companies. Respondents are clusterred by economic sectors. The largest part of respondents are companies from the service sector (57.64\%). Respondents from other sectors: $20.20 \%$ from the trade sector, $19.70 \%$ from the industry sector, $2.76 \%$ from the construction sector.

When analysing the respondents according to the sector of the company's activities and the number of employees (using the crosstabs option - see Table 4), the authors conclude that the majority of respondents from the industrial sector are enterprises with the number of employees ranging from 50 to 249 , while the majority of respondents from the services sector are enterprises which according to the number of employees could be micro enterprises (the number of employees up to nine). In the trade sector, the majority of respondents (according to the number of 
employees) belong to the group of small businesses.

Table 4. Respondents by number of employees (source: created by authors)

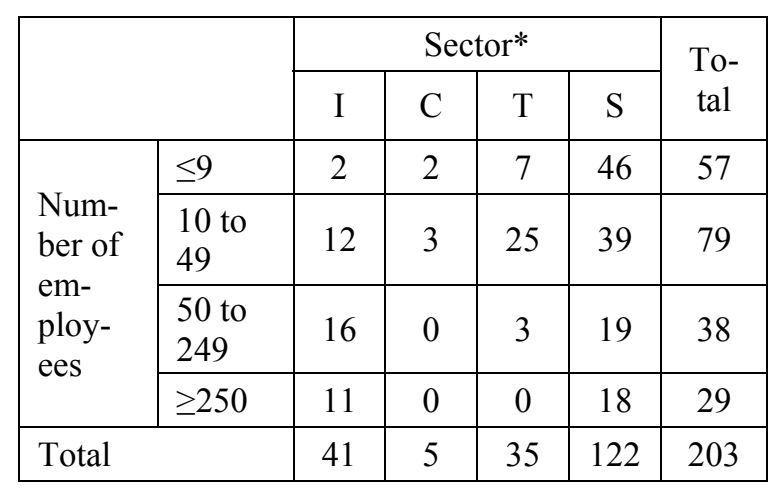

* I - industry, $\mathrm{C}$ - construction, $\mathrm{T}$ - trade, $\mathrm{S}$ - service

The distribution of respondents according to the criterion "length of business operations" in all economic sectors is uniform: almost all respondents have been operating for some time; there is almost the same number of respondents in the groups of companies operating for five to ten years and in the group of companies operating for more than ten years. The number of start-ups is very small - four companies in the services sector. Companies from various parts of Latvia participated in this survey. The authors divided all respondents into two groups: Riga (58.13\%) and regions $(41.87 \%)$.

According to the criterion "annual net turnover", the highest number of respondents is in the services sector. Most of the respondents from the service sector are companies with the lowest net turnover, in the industry sector with an average net turnover, and in the trade sector with a low net turnover (See Table 5).

Table 5. Respondents by number of employees (source: created by authors)

\begin{tabular}{|l|l|c|c|c|c|c|}
\hline \multicolumn{2}{|c|}{} & \multicolumn{4}{|c|}{ Sector* } & \multirow{2}{*}{ Total } \\
\cline { 3 - 7 } \multicolumn{2}{|c|}{} & I & C & T & S & \\
\hline \multirow{3}{*}{$\begin{array}{l}\text { An- } \\
\text { nual } \\
\text { net } \\
\text { sales }\end{array}$} & \begin{tabular}{l}
$<2$ mln eur \\
\cline { 2 - 7 }
\end{tabular} & 9 & 3 & 21 & 80 & 113 \\
\cline { 2 - 7 } & $\begin{array}{l}10 \text { mln eur to } \\
50 \text { mln eur to }\end{array}$ & 12 & 1 & 12 & 25 & 50 \\
\cline { 2 - 7 } & $>50$ mln eur & 4 & 0 & 0 & 11 & 15 \\
\hline Total & 41 & 5 & 35 & 122 & 203 \\
\hline
\end{tabular}

* I - industry, $\mathrm{C}-$ construction, $\mathrm{T}-$ trade, $\mathrm{S}-$ service.
The survey results show that what most Latvian entrepreneurs understand by intellectual capital is the knowledge of the company employees. A relatively small share of respondents (13.3\%) agrees with the authors' definition of intellectual capital - the company's asset that can be transformed into value (both tangible and intangible). Some entrepreneurs indicated that what they understand by intellectual capital is both the employees' knowledge and the company's non-financial and intangible resources (see Figure 1).

The authors conclude that the majority of entrepreneurs do not have an in-depth understanding of the nature of intellectual capital - what they understand by intellectual capital is only one element of intellectual capital. This limited understanding can create stereotypes about the role of intellectual capital in the company's activities, limiting the company's development potential. There is a risk that the company might not pay enough attention to the intellectual capital in their possession because it is not considered as an asset that can create value. One of the reasons could be difficulties in evaluating this asset, as well as problems in calculating the return on the asset.

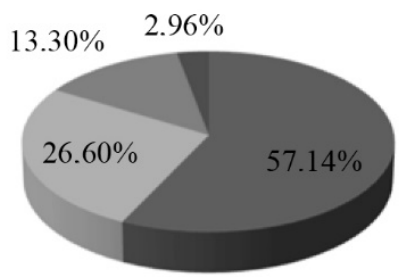

\footnotetext{
- the company employees' knowledge that can be transformed into value

w the company's non-financial and intangible resources that are completely or partly controlled by the company and that rise the company value

- the company's asset that can be transformed into value (both tangible and intangible)

mother
}

Figure 1. Entrepreneurs' opinion of the concept of intellectual capital (source: created by authors)

During the survey, respondents evaluated the importance of intellectual capital elements according to their understanding of the nature of intellectual capital and its structure, indicating which of the intellectual capital elements in their company are more important. The authors have processed the results and created the ranking of these elements according to their importance (1 most important, 2 - important, 3 - least important, 4 - not included). 
Respondents consider the most important elements to be employees' knowledge and experience, which coincides with the majority of respondents' understanding of the nature of intellectual capital - intellectual capital is employees' knowledge (see Table 6). The survey data on the entrepreneurs' understanding of the importance of intellectual capital elements shows a contradictory trend: employees' knowledge and experience, as well as scientific studies and their results are considered significant, whereas labour and $\mathrm{R} \& \mathrm{D}$ costs in Latvia are among the lowest in the European Union. On the one hand, entrepreneurs are aware of the importance of these elements, on the other hand, funding for these elements is low. One explanation might be that statistics can only see official data on company expenses, but in Latvia there is a sufficiently large proportion of shadow economy that prevents an objective assessment of the situation. The size of these costs may also be due to lack of financial resources in companies, especially for scientific research. The third reason, which is difficult to prove and requires additional research, is entrepreneurs' fear that a trained employee can leave the company and start working for a rival company, and that an invention or research results will not be protected from competitors.

Table 6. The importance of elements of intellectual capital in the perception of entrepreneurs (source: created by authors)

\begin{tabular}{|l|c|}
\hline \multicolumn{1}{|c|}{ Element of intellectual capital } & $\begin{array}{c}\text { Importance } \\
\text { (average } \\
\text { statement) }\end{array}$ \\
\hline Employees' knowledge & 1.18 \\
\hline Employees' experience & 1.30 \\
\hline Scientific research and its results & 1.84 \\
\hline Software & 1.88 \\
\hline Brand & 1.92 \\
\hline Patents & 1.93 \\
\hline Data bases & 1.97 \\
\hline Licenses & 1.98 \\
\hline $\begin{array}{l}\text { Information and communication } \\
\text { technologies }\end{array}$ & 1.98 \\
\hline Production technologies & 1.98 \\
\hline Sales and marketing technologies & 2.08 \\
\hline $\begin{array}{l}\text { Business processes, models and } \\
\text { manuals }\end{array}$ & 2.08 \\
\hline Partnership & 2.50 \\
\hline Customer loyalty programs & 2.55 \\
\hline
\end{tabular}

In the last three rows of Table 6, there are descriptions of business management processes, cooperation agreements with partners and customer loyalty programs. These elements of intellectual capital were evaluated by entrepreneurs as significant, but they are less significant in comparison with other elements. The authors assume that entrepreneurs do not associate these elements with their understanding of the nature of intellectual capital, and therefore give them relatively less importance.

The main problem identified by the authors' study is the understanding of the concept of "intellectual capital": most entrepreneurs do not include the aspect of value creation in it. Therefore it can be concluded that entrepreneurs lack a sufficiently deep understanding of intellectual capital and its role in the company development.

\section{Conclusions}

Summing up the definitions and interpretations of the concept of intellectual capital in the scientific literature and normative documents with the results of the survey of Latvian entrepreneurs, the authors conclude that various concepts are used.

The concept "intellectual capital" is used in the management literature and economic literature, the concept "intellectual property" is used in normative acts regulating the protection of intellectual property, the concept "intangible investments" is used in Latvian normative acts regulating accounting, the concept "intangible assets" is used in international accounting standards, and the Commercial Law of Latvia includes the concept "commercial secret". These concepts are not synonymous but complementary.

In both Latvian and international normative acts, the concept of intellectual property is part of the concept of intellectual capital. In addition, intellectual property is included and described in the normative documents from the point of view of legal protection of property. Therefore, its structure contains elements that can be easily identified and it is also possible to determine the usage rights of this intellectual property. This approach has also been used in the normative documents and standards that regulate accounting, further emphasizing the object and purpose of investments.

In the scientific literature, intellectual property is part of intellectual capital. However, when creating a structure of intellectual capital, scientists often include not intellectual property, but its individual elements, such as patents, trademarks, 
copyrights, etc. Intangible assets are also considered as part of intellectual capital, whereas intangible investments are expenses that provide intellectual capital formation and development within the company.

The results of the survey of Latvian entrepreneurs indicate that entrepreneurs lack a deep understanding of the nature of intellectual capital. By intellectual capital entrepreneurs most often understand the employees' knowledge. But when looking at the structure of intellectual capital, they also think that other elements are significant, such as software, scientific research and patents, brands etc.

In the present situation, when there is no consistency in the use of the concept of intellectual capital in the scientific literature and normative acts at the national and international level, it is difficult for an entrepreneur to understand its nature and role in the company development. Consequently, it would be wise to regulate the use of the term in the Latvian normative acts in accordance with internationally recognized terminology.

\section{References}

Bontis, N., Chua, W., \& Keow, C. (2000). Intellectual capital and business performance in Malaysian industries. Journal of Intellectual Capital, 1(1), 85-100. https://doi.org/10.1108/14691930010324188

Campos, E. B., Grupo de Investigación Intellectus. (2012). Intellectus model for the measurement, management and information of intellectual capital. Madrid: Universidad Autónoma de Madrid, IADE.

Chan, K. H. (2009a). Impact of intellectual capital on organizational performance: an empirical study of companies in the Hang Seng Index (Part 1). The Learning Organization, 16(1), 4-21. https://doi.org/10.1108/09696470910927641

Chan, K. H. (2009b). Impact of intellectual capital on organizational performance: an empirical study of companies in the Hang Seng Index (Part 2). The Learning Organization, 16(1), 22-39. https://doi.org/10.1108/09696470910927650

Commercial Law of Latvian Republic. (2000). Retrieved from https://likumi.lv/doc.php?id=5490

Cohen, W., \& Levinthal, D. (1990). Absorptive capacity: a new perspective on learning and innovation. Administrative Science Quarterly, 35(1), 128-152. https://doi.org/10.2307/2393553

Dumay, J. (2009). Intellectual capital measurement: a critical approach. Journal of Intellectual Capital, 10(2), 190210. https://doi.org/10.1108/14691930910952614

Edvinsson, L. (2013). IC 21: reflections from 21 years of IC practice and theory. Journal of Intellectual Capital, 14(1), 163-172. https://doi.org/10.1108/14691931311289075

Edvinsson, L., \& Malone, M. S. (1997). Intellectual capital: realizing your company's true value by finding its hidden brainpower. New York: HarperBusiness.
Garanina, T. (2008). Struktura intelektualjnogo kapitala: voprosi ocenki empiricheskogo analiza. Vestnik SanktPetegburgskogo universiteta, 1, 116-128.

Gogan, L. M., Rennung, F., Istis, G., \& Drahici, A. (2014). A proposed tool for managing intellectual capital in small and medium size enterprises. Procedia Technology, 16, 728-736.

https://doi.org/10.1016/j.protcy.2014.10.022

Grant, R. M. (1996). Toward a knowledge-based theory of the firm. Strategic Management Journal, 7, 109-112. https://doi.org/10.1002/smj.4250171110

Ferenhof, H. A., Durst, S., Bialecki, M. Z., \& Selig, P. M. (2015). Intellectual capital dimensions: state of the art in 2014. Journal of Intellectual Capital, 16(1), 58-100. https://doi.org/10.1108/JIC-02-2014-0021

IFRS. (2002). International Accounting Standards (IAS 38 Intangible Assets). Retrieved from http://www. ifrs.org/IFRSs/Pages/IFRS.aspx

Inkinen, H., Kianto, A., Vahala, M., \& Ritala, P. (2017). Structure of intellectual capital; international comparison. Accounting, Auditing \& Accountibility Journal, 30(5), 1160-1183. https://doi.org/10.1108/AAAJ-11-2015-2291

Intellectual Capital Statement - Made in Europe" (InCaS). (2006). European Commiision. Retrieved from http://www.psych.lse.ac.uk/incas/page114/files/ page114_1.pdf

Itami, H., \& Roehl, T. W. (1987). Mobilizing invisible assets. Cambridge, MA: Harvard University Press.

Jurczak, J. (2008). Intellectual Capital Measurement Methods. Economics and Organization of Enterprise, 1(1), 37-45.

Kianto, A., Andreeva, T., \& Pavlov, J. (2013). The impact of intellectual capital management on company competitiveness and financial performance. Knowledge Management Research and Practice, 11, 12-22. https://doi.org/10.1057/kmrp.2013.9

Lentjušenkova, O., \& Lapiņa, I. (2016). The transformation of the organization's intellectual capital: from resource to capital. The Journal of Intellectual Capital, 17(4), 610-631. https://doi.org/10.1108/JIC-03-2016-0031

Lentjušenkova, O., \& Lapiņa, I. (2015). Factors influencing investments in intellectual capital: case of Latvia. Proceedings of the 19th World Multi-Conference on Systemics, Cybernetics and Informatics (WMSCI 2015) 1 (pp. 82-87). United States of America, Orlando: International Institute of Informatics and Systemics.

Lev, B. (2000). Intangibles: management, measurement and reporting. Washington, D.C.: Brookings Institution Press.

Law On the Annual Financial Statements and Consolidated Financial Statements. (2015). Retrieved from https://likumi.lv/ta/en/id/277779-law-on-the-annualfinancial-statements-and-consolidated-financial-statements

Mkumbuzi, P. (2015). Investment in Employees and Research and Development and the Signalling of the Intellectual Capital by UK Listed Companies. Asian Social Science, 11(21), 148-161. https://doi.org/10.5539/ass.v11n21p148

OECD. (2013). Supporting investment in knowledge capital, growth and innovation. OECD iLibrary. Retrieved from https://www.oecd-ilibrary.org/industry-and-services/supporting-investment-in-knowledge-capitalgrowth-and-innovation_9789264193307-en 
Ortiz, M. A. A. (2009). Analysis and valuation of intellectual capital according to its context. Journal of Intellectual Capital, 10(3), 451-482. https://doi.org/10.1108/14691930910977833

Petrick, J., Scherer, R., Brodzinski, J., Quinn, J., \& Ainina, M. (1999). Global leadership skills and reputational capital: intangible resources for sustainable competitive advantage. Academy of Management Executive, 13(1), 58-69.

Petty, R., \& Guthrie, J. (2000). Intellectual capital literature review: measurement, reporting and management. Journal of Intellectual Capital, 1(2), 155-176.

Pulic, A. (2000). VAIC ${ }^{\mathrm{TM}}$ - an accounting tool for IC management. International Journal Technology Management, 20(5/6/7/8), 702-714. https://doi.org/10.1504/IJTM.2000.002891

Puntillo, P. (2009). Intellectual capital and business performance. Evidence from Italian banking industry. Electronic Journal of Corporate Finance, 4(2), 97-115.

Reinhardt, R., Bornemann, M., Pawlowsky, P., \& Schneider, U. (2003). Intellectual capital and knowledge management: perspectives on measuring knowledge in Dierkes, Antal, Child \& Nonaka (Eds.), Handbook of organizational learning and knowledge. New York: Oxford University Press.

Roos, G., \& Roos, J. (1997). Measuring your company's intellectual performance. Long Range Planning, Special Issue on Intellectual Capital, 30(3), 413-426. https://doi.org/10.1016/S0024-6301(97)90260-0

Rozenfelds, J. (2004). Intelektuālais ìpašums. Rīga: Apgāds Zvaigzne ABC.

Stewart, T. A. (1997). Intellectual capital: the new wealth of organizations. New York: Doubleday.
Stewart, T. A. (1991). Brainpower: intellectual capital is becoming corporate America's most valuable asset and can be its sharpest competitive weapon; the challenge is to find what you have - and use it. Fortune, 123(1), 44-60.

Sveiby, K. E. (2001). A knowledge-based theory of the firm to guide in strategy formulation. Journal of Intellectual Capital, 2(4), 344-358. https://doi.org/10.1108/14691930110409651

Subramaniam, M. (2005). The influence of intellectual capital on the types of innovative capabilities. Academy of Management Journal, 48(3), 450-463. https://doi.org/10.5465/amj.2005.17407911

Tseng, C., \& Goo, Y. (2005). Intellectual capital and corporate value in an emerging economy: empirical study of Taiwanese manufacturers. R\&D Management, 5(2), 187-201. https://doi.org/10.1111/j.1467-9310.2005.00382.x

Wang, W.-Y., \& Chang, C. (2005). Intellectual capital and performance in causal models: evidence from the information technology industry in Taiwan. Journal of Intellectual Capital, 6(2), 222-236. https://doi.org/10.1108/14691930510592816

WIPO. (2004). WIPO intellectual property handbook. Retrieved from http://www.wipo.int/edocs/pubdocs/en/ intproperty/489/wipo_pub_489.pdf

Zack, M. (2003). Rethinking the knowledge-based organization. Sloan Management Review, 44(4), 67-71.

Zéghal, D., \& Maaloul, A. (2010). Analyzing value added as an indicator of intellectual capital and its consequences on company performance. Journal of Intellectual Capital, 11(1), 39-60.

https://doi.org/10.1108/14691931011013325 